\title{
Sosyal Medya Pazarlamasında Farklılaştırıcı Bir Unsur Olarak İçerik Yönetimi Konusuna İletişimsel Bir Yaklaşım
}

\author{
A Communicational Approach to Content Management Concepts as a \\ Differentiating Factor in Social Media Marketing
}

Doç. Dr. Ebru ÖZGEN, Marmara Üniversitesi İletişim Fakültesi, Halkla İlişkiler ve Tanıtım Bölümü

Öğr. Gör. Hüsnur DOYMUŞ (M.A.), Marmara Üniversitesi İletişim Fakültesi Gazetecilik Bölümü, husnurdoymus@hotmail.com

ÖZET Bu çalışmada; sosyal medya ortamlarnnın markalar açısından daha etkili kullanılabilmesi için farklı içerik yaratmanın önemli bir ayırt edici özellik olduğu düşüncesinden yola çıkılarak, sosyal medya pazarlamasında özellikle içerik yönetimi odaklı pazarlamanın yaratıcı bir strateji olduğu düşüncesine ilişkin değerlendirmeler, çalışmanın temel prensibini oluşturmaktadır.

Bu çalışmada; sistematik derleme yöntem arayışı kullanılmıştır.

Anahtar Sözcükler Sosyal Medya, Sosyal Medya Pazarlamasi; Sosyal Medyada İçerik Pazarlamasl; Sosyal Medyada Topluluk Oluşturma.

\begin{abstract}
Social media has made it possible for one person to communicate with hundreds or even thousands of other people about products and the companies that provide them. Social media applications can directly engage consumers in the creative process by both producing and distributing information through collaborative writing, content sharing, social networking, social bookmarking, The purpose of this article is to emphasize the importance of content management in social media marketing.
\end{abstract}

Key Words Social Media, Socail Media Marketing, Content Marketing in Social Media; Social Media Community. 


\section{Giriş}

Sokrates' in yaşadığ1 ve sözlü iletişimin hâkim olduğu günlerden bugünlere çok şey değişti. Hala en güvenilir iletişim biçiminin yüz yüze iletişim olduğu ve ikna sürecinin bu iletişim biçimiyle daha etkin bir biçimde sağlandığı bilinse de; teknoloji çok farklı ortamları ve medya kanallarını, markaların iletişim yöntemleri içine dahil etmiştir.

İnsanoğlu; sosyalleşme, başkalarına dayanma, paylaşımda bulunma ihtiyacı duyar. Teknolojinin getirdiği yeni ortamlar insanın bu ihtiyacını farklı ortamlar aracılığıyla gidermek için ideal yollar bulmakta ve bu noktada birey zaman ve mekan kavramından bağımsız daha çok sosyalleştiği bir ortamın içerisinde olduğu algısına sahip olmaktadır. Sosyal medyanın bireyler ve toplumlar üzerindeki etkileri konusunda günümüzde pek çok araştırma farklı boyutlarıyla ele alınmış olmakla birlikte bu araştırma sonuçlarına ilişkin henüz tam bir ortak noktada buluşulamamış ancak kullanımının yaygınlaşması nedeniyle, nasıl daha etkili kullanılması gerektiğine ilişkin araştırmalar yapılması ve deneyimler oluşturulması yoluna gidilmektedir.

Kişilerin farklı amaçlar ve içeriklerle birbirleriyle iletişim kurmalarını ve bilgi alışverişinde bulunmalarını sağlayan haberleşme altyapısı veya bir protokol aracılığıyla güvenilir sıralı ve bir uçtan diğer uca bilgi aktaran şebekeler topluluğunun internet olarak tanımlandığını biliyoruz. (Mehmet Marangoz,Burak Yeşildă̆, Işıl Arıkan Saltık, 2012:59)

IP internet protokol olarak adlandırılan bu protokol sayesinde bir nevi ortak bir dil oluşturularak yüksek kapasiteli telefon hatları üzerinden bilgisayarlar arasında iletişim olanağ1 yaratılmaktadır.(Erol,2001:57)

İnternetin sağladığı olanaklar gün geçtikçe şekil değiştirmiş, web 1.0'dan web 2.0'a geçişle birlikte "sosyal medya" dediğimiz interaktif ortamlar, internet dünyasındaki yerini almıştır. Örneğin; 2010 yılı itibariyle kullanıcı sayısı dünya genelinde 500 milyonu aşan Facebook web otoritelerince teknik açıdan en başarılı web 2.0 uygulaması olarak belirtilmektedir. (Biçen\&Çavuş,2010: 04-07) 
Bu açıdan bakıldığında, sosyal ağlar ticari faaliyetler ve ekonomik gelişim anlamında önemli fırsatlar yaratmaktadır. Kullanıcılar kendi ürün ve hizmetleri ile fiyatları hakkında bilgi paylaşarak işletmelerin web site ve hizmet popülaritesini arttırabilmektedirler. (Lea vd.,2006)

Özellikle bu noktada, neden sosyal medya iletişimine katılmak gerekliliği konusunda söylenmesi gereken; marka erişiminin arttırılması, markanın insani bir dokunuş kazanması, hedef kitlesi ile etkin ve interaktif bir iletişimin sağlanması ve marka toplulukları kurularak bu toplulukların beyin gücünden faydalanılması gibi bazı etkenler karşımıza çıkmaktadır.

Yüzdelerle sosyal medya hakkında bazı kullanıcı oranlarını, sosyal medya ortamlarının neden etkili olduğuna dair bir veri sunacaktır; kullanıcıların \%57'si bir markayla sosyal medya üzerinden iletişime geçiyor, \%40'1 en az bir marka sayfasını takip ediyor, \%20'si ürün araştırmak için en az haftada iki kez sosyal medya araştırması yapıyor, \%42'si bir ürün ve marka hakkında bir şey paylaşıyor, \%33'ü bir ürün hakkında yorum yapıyor, \%31'i satın almaya ikna oluyor, \%20'si tavsiye ediyor, \%8'in farkındalığı artıyor (Yılmaz; 2013: 60).

İnternet nasıl kullanılıyor konusuna ilişkin bir tablo sunmak gerekirse;

Tablo: İnternet Kullanım Amaçları

\begin{tabular}{|c|c|c|c|c|c|c|}
\hline $\begin{array}{l}\text { SEÇiLMiş } \\
\text { KATAGORILER }\end{array}$ & TÜRKIYYE & INGILTERE & BREZILYA & çiN & HINDISTAN & RUSYA \\
\hline \multicolumn{7}{|l|}{ ARAMA } \\
\hline NAVIGASYON & $94 \%$ & $93 \%$ & $81 \%$ & $64 \%$ & $79 \%$ & $65 \%$ \\
\hline $\begin{array}{l}\text { SOHBET } \\
\text { KANALLARI }\end{array}$ & $92 \%$ & $91 \%$ & $82 \%$ & $49 \%$ & $77 \%$ & $66 \%$ \\
\hline EĞLENCE & $87 \%$ & $92 \%$ & $77 \%$ & $62 \%$ & $71 \%$ & $65 \%$ \\
\hline ALIŞVERİ̧ & $68 \%$ & $83 \%$ & $65 \%$ & $47 \%$ & $45 \%$ & $43 \%$ \\
\hline MULTIMEDA & $79 \%$ & $73 \%$ & $63 \%$ & $49 \%$ & $53 \%$ & $50 \%$ \\
\hline HABER/BILGI & $80 \%$ & $78 \%$ & $66 \%$ & $47 \%$ & $47 \%$ & $47 \%$ \\
\hline OYUN & $71 \%$ & $53 \%$ & $54 \%$ & $49 \%$ & $28 \%$ & $46 \%$ \\
\hline SPOR & $50 \%$ & $47 \%$ & $39 \%$ & $19 \%$ & $28 \%$ & $13 \%$ \\
\hline
\end{tabular}

Kaynak: Mike Read, "State of the Turkish Internet", ComScore Press\&Events, akt. SosyalMedyaTurkiye, Yayın tarihi: 01.11.2010, www.socialmediatr.com/blog/turk-internet-kullanicisinin-profili/, Erişim tarihi: 02.05.2011. 
$\mathrm{Bu}$ tablonun sunduğu veriler, sosyal medya ortamlarının kullanıcılara farklı bir içerik sunması açısından önem taşımaktadır.

Sosyal medya iletişiminin en önemli kısmı tüketiciyi önceden hazırlanan içeriklerden oluşan bir alana davet etmek yerine, bulundukları yerde, etkileşimde bulundukları şekilde iletişim kurmayı hedef alır. Dolayısıyla bu açıdan bakıldığında, daha etkin bir iletişim ortamı görüntüsündedir.

Sosyal medya reklam açısından da önemli bir mecra olarak karşımıza çıkmaktadır; IAB (Internet Architecture Board)'nin Mayıs 2009'da yayınladığı “Sosyal Reklam: En iyi uygulamalar" raporunda yayınlanan tanımına göre; kullanıcı izniyle kullanıcının etkileşimde bulunduğu platformda reklam mesajını kullanıcının bilgisi ile birlikte teşhir eden ve paylaşan reklam formudur. Reklam içeriği; reklam içeriği, hedefleme ve işlevsellik açısından bölümlendirilebilir(Brand Age;2013;2).

Diğer bir sosyal medya ortamı; markalı platformlardır; markalar kendi oluşturdukları topluluk platformları ile de tüketicilerine ulaşarak markanın duygusal bir bağ kurmasını sağlamaktadır.

Marka Toplulukları (Brand Communities) Kimlik gelişimi, topluluk bağlamında anlaşılmaktadır. Burada "topluluk" kavramından kasıt nedir, gibi bir soru karşımıza gelebilir. Topluluklar herhangi bir yerde ve her yerde vardır - okullarda, arkadaşlar arasında, din kurumlarında, siyasi partilerde, hatta belli bir yaşam tarzını tanıtan tüketici markalarında. Marka toplulukları dediğimiz şey, marka tarafından tanıtılan belli yaşam tarzına bağllık yoluyla bireye anlam kazanma ve benlik duygusu fırsatını sunmaktadır. Marka topluluğu fikrini ortaya atan, De Paul Üniversitesi Pazarlama Bölümü'nden Doç. Albert Muniz ve Wisconsin School of Business Pazarlama Bölümü'nden Prof. Thomas O'Guinn, marka topluluğunu: 'Bir markanın hayranları arasındaki bir dizi yapısal sosyal ilişkilere dayalı, uzmanlaşmış, coğrafi sınırları olmayan bir topluluk" olarak tanımlarlar. Marka toplulukları bir markanın üst sosyal yapısının segmentleri olarak görülür ve markanın süregelen mirasında hayati bir rol oynarlar. Kimlik gelişiminde toplumun önemini 
dikkate alırsak, marka topluluklarının, vefa özelliğinin, ya da diğer bir deyişle sadakatin gelişimini nasıl desteklediklerini de görebiliriz. Kült Markalamanın Gücü (The Power of Cult Branding) adlı kitapta Harley-Davidson, sonsuz müşteri sadakatine örnek olan dokuz marka arasında gösterilmiştir. Harley-Davidson başlangıçta, kırsal alanlarda bedensel işçi olarak çalışan bekar erkekler tarafından benimsenmişken, bugünkü Harley topluluğu Amerika'nın karma profilini yansıtmaktadır. Ne tür bir iş yaptığınız bu canlı tüketici kültüründe önemli değildir. Dükkan sahibi, müteahhit, demirci, öğretmen, doktor ya da avukat da olsanız üyelik size açıktır. Aslında yazarlara göre "Kült Markaların Altın Kuralları"ndan biri de, kapsayıcı nitelikleridir. Harley sahipleri uzun yol sevgisini, yolculukla gelen özgürlüğü ve Harley ailesine üyeliği paylaşırlar. Bir zamanlar kanun kaçağı gibi görülen statüleri, yakından incelendiğinde, ait olmaya yönelik insani ihtiyaçlarını karşılamak üzere toplu Harley-Davidson deneyimine katılmış bir grup birey biçimine dönüşür (http://thebrandage.com/neden-ait-oluruz-marka-topluluklarinin-sosyolojik-ve-psikolojikanalizi/).

Dolayısıyla topluluk yaratmak, tutkulu tüketici ve izleyici yaratmak açısından önemlidir. Tüketicilerle aradaki köprü, markanıza mı yoksa başka aracılara mı aittir? Kendi sosyal platformunu kuran bir marka aradaki bütün aracıları kaldırarak; başka bir anlatımla okyanusta küçük bir göl olmaktansa kendi denizini kurmayı başarmış olacaklardır. Bu anlamda da marka, yarattığı toplulukla tüketicine kendi deneyimini sunmuş olacaktır. Çünkü; veriler göstermektedir ki; tüketiciler bir araya geldiklerinde en çok birebir yaşadıkları deneyimleri hatırlar, dolayısıyla burada amaç aidiyet yaratarak "ortaklık" oluşturmaktır. Bu konuda Subaru markasının yaptığı; her Pazar üzerlerinde "I love Subaru" tshirtleriyle köpeklerini gezdiren marka topluluğu da burada bir örnek olarak verilebilir.

\section{Sosyal Medya Pazarlaması}

Sosyal medya pazarlaması, sosyal medya sitelerini kullanarak internet üzerinde görünürlüğü artırmak ve mal ve hizmetleri tutundurmak olarak tanımlanabilir. Sosyal medya siteleri, sosyal (ve iş) ağları oluşturarak fikir ve bilgi değişimlerini sağlar. (Ontario,2008).Weinberg(2009:3). 
Sosyal medya pazarlamasını, bireyleri online sosyal kanallar yoluyla kendi web sitelerini, ürünlerini ya da hizmetlerini tanıtmak ve geleneksel reklam kanallarıyla mümkün olmayacak çok geniş topluluklarla iletişim ve bağlantı kurmak için yetkilendiren bir süreç olarak, (Tuten, 2008: 19) marka olmayı ve iletişim amaçlarını yerine getirmek için sosyal ağları (Youtube, Facebook, MySpace gibi) sanal dünyaları (Second Life, There ve Kaneva gibi) sosyal haber sitelerini (Digg ve Delicious gibi) ve sosyal fikir paylaşım sitelerini (Epinions gibi) kapsayan sosyal toplulukların kültürel bağlamda kullanıldığı bir online reklam formu olarak belirtilmektedir (Akar,s.37).

Sosyal medya pazarlaması ile başarılmak istenen amaçlar aşağıdaki unsurlarla özetlenebilir (Weinberg, 2009: 6);

Marka farkındalı̆̆ı yaratma,

Fikir liderlerini tanımlama,

Tüketici davranışını ve kalabalık topluluklardan oluşan dışsal kaynakları (ürün geliştirme

fikri için bir araya gelen müşteri gruplarını) inceleme,

Yeni pazarlama stratejileri için fikir geliştirme,

Şirket web sitesine trafiği yönlendirme,

Spesifik mesajları viral olarak yayma,

Site yapışkanlığını artırma, marka mesajının teşhir süresini uzatma,

Sosyal arama sınıflandırmasını (organik linkler yoluyla) geliştirme,

Markanın itibar ve imajını artırma ve içselleşmesini destekleme,

Ürün satışlarını artırma.,

Pazarlama amaçlarını etkili bir şekilde başarma,

Karşılıklı konuşmaları başlatma ve sürdürme gibi amaçları taşır.

Pazarlama homojen olmadığından birçok işletme kitlesel pazarlamadan uzaklaşarak hedef pazarlama uygulamasına yönelmektedir. Bu uygulamada pazarı bölümlere ayırma ve bunlardan bir ya da birkaçını seçerek her bölüme uygun ürün geliştirme ve uygun pazarlama karması oluşturma temel pazarlama faaliyetidir. (Armstrong ve Kotler,2000) 
İşletmeler hedef pazarlarını belirledikten sonra, pazarı bölümleyerek bir veya daha çok pazarlama karmasıly belirledikleri pazara yönelirler. İnternet ve sosyal medya yaygınlaşmasıyla pazarı bölümleme kolaylaşarak, etkisi ölçülebilir hale gelmiştir. Sosyal ağlar, işletmelerin markaları, imajları ve satış gelirleri için dikkate aldıkları platform haline gelmiştir.

Örneğin Facebook markalara, müşterilerini tanıdık bir ortam çerçevesinde bir markanın veya yaratıcı bir fikrin kalbine götürebilecekleri bir mekan sağlamıştır. Facebook ekosisteminin niteliğini anlayan ve değerlendiren, kampanyalarını bunun etrafında oluşturan reklam verenler en büyük ödülleri alacaklardır. Facebook'u kullanan pazarlamacılar, müşterilerinin yaşamlarına, markanın faydalarının ötesine geçen değer ilave edebilirler. Müşterilerinin önem verdiği bir şeyi -bu bir bilgi, ipucu, tavsiye, özet veya eğlenceli herhangi bir şey olabilir- sunabilirler ve onların bunu başkalarıyla paylaşmasını sağlayabilirler. Facebook üzerinden müşterilerle ilişki kurmanın bu yönü üzerinde ustalaşan markalar, gerçek kazanan olma yolundadırlar (Blaney, 2013: 45).

Elbette sosyal medya ortamlarının eleştirilecek ve dezavantaj olarak markalarının önüne çıkan birçok konudan söz edilebilir ancak bu unsurlar başka bir çalışmanın konusu olacak şekilde tarafımızca tasarlanmıştır.

Sosyal medya pazarlamasında yukarıda sayılan amaçlara ulaşabilmenin en temel yolu olarak “içerik yönetimi” nin ayrıştırıcı bir özellik olduğundan hareketle, esas itibarıyla pazar bölümlendirilmesi yapıldıktan ve amaca uygun stratejik ortamlar seçildikte sonra yapılması gereken içeriğin farklı biçimde üretilmesidir.

\section{Sosyal Medyada İçerik Yönetimi}

Bloglar, Youtube, Facebook, Twitter ve diğer çevrimiçi platformlar markaların müşterileriyle ya da potansiyel müşterileriyle doğrudan ilişki kurmaları için önemli bir fırsat sunmaktadır. Ancak burada önemli olan kayda değer bir içerik oluşturmak ve bunu tutarlı bir biçimde sunmaktır. 
Pazarlamanın temel taşı olarak içerik yaratmak daha spesifik olarak şu unsurları başarabilir(Handley,Chapman, 2012:37)

Müşterileri çekmek,

Müşterileri satın almayı düşündükleri bir şey hakkında eğitmek,

Direnişin üstesinden gelmek ve itirazları ele almak,

Sektörde güvenirliği, itibarı ve uzmanlığı tesis etmek,

Markanın hikayesini anlatmak,

Sosyal ağlar yoluyla kulaktan kulağa yayılmak,

Bir hayran tabanı yaratmak ve müşterilerin markayı sevmelerine ilham vermek,

Ani satın almaları tetiklemek.

Yukarıdaki unsurlar göz önüne alındığında; içerik yönetimi bir içerik pazarlaması olarak da adlandırılmaktadır. İçerik pazarlaması en katı tanımı itibarıyla, içerik yaratılması anlamına gelmektedir. Markaya ait (owned), kazanışmış (earned), medya tiplerinde karşımıza çıkan içerik pazarlaması, eğer paralı (paid) medyada yer alırsa reklam haline gelmektedir. Aslında burada temel amaç, müşteriyi çekebilmektir.

Yukarıda sayılan unsurları sosyal medya ortamları yoluyla elde edebilmek için iyi içerik sunmak bir rekabet avantajı sunar. İyi içerik sunmak, markanın hedef kitlesini en iyi şekilde tanımaktan geçer. Böylelikle hedef kitleye uygun orijinal bilgileri sunmak onları harekete geçirmek; markanın misyonunu, değerlerini empatik bir dille anlatarak yeni tasarımlar yoluyla marka hakkında iyi kanaatler oluşması sağlanabilir. Burada belirtilmesi gereken en temel nokta, markanın güçlü yönlerine odaklanılması gerekliliğidir.

İyi içerik stratejisi oluşturabilmek için bazı soruları markanın kendisine sorması ve bu cevaplara uygun strateji/leri geliştirmesi gereklidir. Peki, sorulması gereken sorular nedir? (Handley,Champman:53)

Yarattığınız içeriği neden yaratıyorsunuz? (Hedefleriniz neler?) 


\section{Hedef kitleniz kim? Siz kimsiniz?}

\section{İçeriğin neyi elde etmesini istiyorsunuz? İçeriği ne zaman ve nasıl geliştireceksiniz?}

\section{Nerede yayınlayacaksınız?}

Hedef kitleye uygun içeriğin amacı belirlenerek, nasıl uygulanacağı,nerede ve ne zaman yapılacağı hangi ölçümleme kriterlerinin kullanılarak, amaca ulaşılıp ulaşılmadığı denetlenmelidir.

Orijinal bir içerik sunabilmek, rakiplerin sunmuş olduğu tüm içeriklerden farklı olmayı başarabilmek ve bunu yaparken de stratejik olabilmek, aynı zamanda hedef kitleye karşı empati sağlayabilmek için yukarıdaki soruların cevapları alınarak içerik yönetimine başlanmalıdır. Böylelikle toplulukları büyütmek ve toplulukların başkalarına da markadan bahsetmesini sağlamak mümkün olacaktır. Önemli olan sosyal medya ortamlarında işe yarar bir trafik oluşmasını sağlamaktır. Temel bir başarı kriteri ise oluşturulan içeriğin hedeflenen noktaya ulaşıp ulaşmadığını denetleyecek ölçümleme kriterinin belirlenmesidir.

Bilgi Teknolojisinin kullanımı müşteri sadakati yaratmada büyük bir güce sahip olmasına karşın iyi ve doğru biçimde uygulanmazsa, başarısızlıkların ve müşterilerde hayal kırıklıklarına neden olabilmenin kaynağı da olabilmektedir. Bazı önlemleri alarak olumsuz sonuçların doğmasına neden olabilecek uygulamalardan kaçınabilmek olanaklıdır. Bu açıklamalara uygun e-hizmet sorunlarını önlemedeki eylemler kısaca şöyle özetlenebilir(Odabaşı, 2013: 85-89):

Orada ve Hızlı Olmak: Ağır çalışan ve kullanıcı dostu olmayan sitelerden kaçmak ve rakiplerininkine gitmek bir tık kadar uzaktadır.

Site içi aramayı basit hale getirmek: Müşteri o sayfaya bağlandığında, müşteri hizmetleri sayfasına çok rahat ve hızlı biçimde bağlanabilmelidir.

Hızlı yanıtlamayı gerçekleştirmek: Yantlama zamanı, ev hizmetleri için çok önemli hale gelmiştir. E-postayla yanıtlamalarda en fazla 24 saat uygun bir süre olarak düşünülmelidir. 
İletişim seçenekleri sunmak: Sohbet odaları, etkileşimli videolar, telefon gibi seçenekler her zaman elde olmalıdır.

Biçime ve işlevlere özen göstermek: Karmaşık ve anlaşılması zor olan biçimlerin müşteriler için zorluklar yarattığının farkında olunabilmelidir. Bunun için yapılması gerekenler müşteri hareketlerini izlemek, hizmet düzeylerini kıyaslamak, siteyi öğrenen bir site haline dönüştürmek, sürekli olan bir e-ilişki geliştirmek, daha güçlü ve yüksek bir sadakat geliştirmek amaçlanmalıdır.

Sosyal medyada farklı içerik yaratmak; ayrışmak ve bu sayede diğer markalardan farklı olmak için önemli bir stratejidir. Ancak temel olarak göz ardı edilmemesi gereken durum ise; markaların kendilerini tamamen facebook, twitter v.b.gibi aracı ortamlar üzerinden konumlandırmaması gerekliliğidir. Burada sorulması gereken soru: Bir gün bu aracı ortamların varlığı ortadan kalkarsa (Facebook, Twitter v.s olmadığında) ne yapacaklarıdır? Bu yüzden esas konu; markaların kendi ortamlarını yaratması ve bu ortamlarda farklı içerik oluşturması zorunluluğudur.

Sosyal medyada farklı içerik sunmak müşteriyle arada sosyal bir bağlılık da sağlayacaktır. Peki bu sosyal bağlllık nasıl ölçülür (MediaCat, Nisan 2013, Sosyal Medya Eki:12-13):

- Marka, fanlarıyla kuracağı iletişim için açık bir hat oluşturmaktadır. Bu da markanın fanları için paylaşılabilir içerik gönderimini zorunlu kılmaktadır. Böylelikle takipçiler konuya dahil olup, marka ile bağlantı kurabilmektedirler.

- Marka kendi fanlarının sorularının ne kadarını cevaplamaktadır sorusu önem arz etmektedir. Kriter olarak, tüm gelen soruların en az \%65 inin yanıtlanması gerektiği yönündedir. Haziran 2012' de ortalama endüstri yanıt oranı (response rate) yüzde 30 ile sınırlı kalmıştır.

- Marka sayfasının özellikle müşteri hizmetleri sitesi açısından önemi artmaktadır. Bu nedenle sorulara yanıt vermeyen markalar, fanlarının gözünde itici duruma düşmektedir.

$\mathrm{Bu}$ durum markanın yönettiği itibar algısına da gölge düşürme tehlikesini ortaya çıkaracaktır. Farklı içerik sunmanın dışında, müşterilerinin sorularını yanıtlarken de yine 
farklı içerikle karşılarında olmak bağlılı̆̆ı arttıracak ve iletişimsel açıdan bir başarı yakalanacaktır.

İçerik yönetimi bir bütçe gerektirmektedir. Ve sosyal medya içerik pazarlamasına ayrılan bütçeler her geçen gün artmaktadır. Markalar, içerik yönetimi konusunda organizasyon şemasında yer verdiği sürece bu konuya ayıracakları bütçeyi de belirlemeli ve bu doğrultuda en iyi ve en farklı uygulama ortaya çıartılmalıdır.

Farklı içerik yaratmanın en önemli unsurlarından biri, müşteriyi anlamak için onu dinleme sürecidir. Dinleme, başarılı iletişimin en önemli özelliğidir. Dinleme süreci iletişimin daimi bir parçası olmalı ve bu süreçte sürekli bir döngüde kalınmalıdır. İnsanlar için neyin önemli olduğunu anlamak onlara daha doğru ve sağlıklı bir tonla yaklaşmak açısından yardımcı olacak, bu da farklı bir içerik yaratmayı sağlayacaktır.

\section{Sonuç}

Sosyal medya ortamlarından faydalanmak markalar için bir zorunluluk halini almıştır. Ancak; sosyal medyada olmak ile var olmak aynı şey değildir. Dolayısıyla sosyal medya ortamlarında var olabilmek için müşterilere deneyim yaşatmak ve topluluklar oluşturarak; markanın bir virüs gibi yayılmasını sağlamak gereklidir. Ancak bu yayılmayı sağlamak için içeriğin doğru yönetilmesi, orijinal içerik sunulması ve bu içeriğin ilgi çekmesi ve bu ortamlarda müşterileri zaman geçirmeye ikna etmesi gereklidir. İçerik yönetimin bazı kurallarını bilmeden markaların bunu başarması mümkün gözükmemektedir.

Markalar, öncelikle hangi içeriklerin işe yaradığını görmektedirler. Ayrıca rakiplerinin neler yaptıklarına da şahit olmaktadırlar. Markalar bu verileri analiz ederek sosyal medyadaki müşteri hizmetlerini düzenleyebilir, rakipleriyle kendilerini karşılaştırarak eksi ve artılarını tartabilirler. Ve tüm bu analizlerin sonucunda farklı bir içerik yaratmak ve bunu kullanıcılarıyla paylaşarak fark yaratmak mümkün olacaktır. Burada vurgulanması gereken içeriği geliştirmek, zenginleştirmek ve farklılaştırmak bir pazarlama yöntemi olarak kabul edilmelidir. 
Sosyal medyada müşteriye dokunabilmek için şeffaf olmak, negatif içeriklere empatiyle yaklaşabilmek, bu içeriklere cevap vermek ve müşteriyi bu anlamda tatmin etmek, görsel ve video içeriklerin farklılık yarattığını unutmamak, 7/24 müşteriyi dinlemek ve onlara geri dönüş yapmak, sosyal medyanın diliyle konuşmayı başarabilmek, şikayetlere ve sorulara karşı hazırlıklı olmak gereklidir.

Türkiye' de yaklaşık 32 milyon kullanıcının olduğu sosyal medya ortamları markaların iş hedeflerini gerçekleştirmeleri açısından iyi bir stratejiyle yönetmeleri gereken ve ayrıca farklı içerik sunmak adına strateji üretmeleri gereken bir ortamdır.

Sosyal medyada hangi ortam seçilecek olursa olsun, konunun kilit noktası içerik üretmeye dayanmaktadır. Farklı bir içerik üretilmediği sürece bunun dikkat çekmesi pek mümkün gözükmemektedir. Çünkü geleneksel medyada olduğu gibi sosyal medyada da "veri dumanı" her tarafı kaplamış bulunmaktadır. Bu dumanın içinde, markayı görünür kılmak, iletişim mesajını iletebilmek ve iş sonuçlarına ulaşabilmek farklı bir içerik sunmakla mümkün olacaktır.

\section{KAYNAKÇA}

Akar , E (2009), Web 2.0'la Değişen Pazarlama ve Yeni Kuralları, Pazarlama ve İletişim Kültürü Dergisi, (Bahar), s:50-55.

Akar, E. (2011) Sosyal Medya Pazarlaması Sosyal Web'te Pazarlama Stratejileri, 2.Basım, Efil Yayınevi, Ankara.

Alabay, M. ,Sosyal Medyada Tüketiciler ve Pazar Bölümleme Uygulamaları, http://inettr.org.tr/inetconf16/bildiri/11.pdf.

Armstrong, G. Ve Kotler P. (2000) Marketing: An Introduction, 5th Edition, Prentice Hall Inc.

Biçen, H. \& Çavuş, N. (2010). The most preferred social network sites by students, World Conference on Educational Sciences (WCES), February 04-07, 2010, Turkey.

Erol, A. (2001). Elektronik Ticaret Uygulamaları, Finansmanı ve Muhasebeleştirilmesi,TC Marmara Üniversitesi Sosyal Bilimler Enstitüsü, İşletme Anabilimdalı Muhasebe- Finansman Bilim Dalı Yüksek lisans Tezi, İstanbul.

Handley, A. Chapman, C. (2013). Dijital Çağda İçerik Yönetiminin Kuralları, MediaCat; İstanbul. 
Blaney, Harward Business Review (2013). Reklamın Geleceği, Mart Sayısı.

Lea, B.R., Yu, W.B. Maguluru, N. \& Nichols, M., 2006, Enhancing business networks using social network based virtual communities, Industrial Management and Data Systems, 106: 121-138.

Marangoz, M., Yeşildağ, B. Saltık Arıkan, I., 2012, E-Ticaret İşletmelerinin Web ve sosyal A $\breve{g}$ Sitelerinin İçerik Analiz Yöntemiyle İncelenmesi, İnternet Uygulamaları ve Yönetimi Dergisi, Cilt 3, Sayı 2.

MediaCat, Nisan 2013, Sosyal Medya Eki, Y1l 21; Sayı 219.

Odabaşı. Y. (2013). Kalıcı Başarı İçin Müşteri Hizmetleri, MediaCat, İstanbul.

Ontario (2008), Social Medya Marketing İntroduction to Social Media Marketing, http://www.bruce.on.ca/tools/Social_Media_Marketing.pdf (20.10.2009).

Sevinç, S. (2012). Pazarlama İletişiminde Sosyal Medya, Optimist Yayınları, İstanbul.

Weinberg, T. (2009), The New Community Rules: Marketing on The Social Web, O'Reilly: California.

Tuten, T. L. 2008, Advertising 2.0, Social Media Marketing in A Web 2.0 World, Praeger: Westport.

Yılmaz, E. (2013). “Markanızın Sosyal Medyada Olması İçin 32.000 Neden", 360 Derece Markalamada Pazarlama İletişimi, BrandAge Dergisi Eki, Sayı 2. 